\title{
Following the Cap-Figure in Majapahit Temple Reliefs
}




\title{
Verhandelingen van het Koninklijk Instituut voor Taal-, Land- en Volkenkunde
}

\author{
Edited by \\ Rosemarijn Hoefte \\ KITLV, Leiden \\ Henk Schulte Nordholt \\ KITLV, Leiden \\ Editorial Board \\ Michael Laffan \\ Princeton University \\ Adrian Vickers \\ Sydney University \\ Anna Tsing \\ University of California Santa Cruz
}

VOLUME 280

The titles published in this series are listed at brill.com/vki 


\section{Following the Cap-Figure in Majapahit Temple Reliefs}

A New Look at the Religious Function

of East Javanese Temples,

Fourteenth and Fifteenth Centuries

By

Lydia Kieven

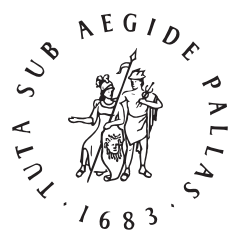

B R I L L 


\section{B R I L L \\ OPEN}

This is an open access title distributed under the terms of the Creative Commons Attribution-Noncommercial-NonDerivative 3.0 Unported (CGBY-NC-ND 3.0) License, which permits any noncommercial use, and distribution, provided no alterations are made and the original author(s) and source are credited.

Shortly before the printing of this book, Suryo Prawiroatmojo has passed away on 8 May 2013. As an activist in environmental and cultural affairs, he initiated the 'Budaya Panji' ('Panji Culture') and strongly supported my research over the years. All the more he made me apply my expertise on the Panji theme in his educational activities on revitalizing the Javanese ancient culture. His ashes were buried at Candi Kendalisodo on the slopes of Mount Penanggungan the fascination of which both of us shared. He would have loved so much to hold this book in his hands. I dedicate this work to him.

Cover: samgobin.nl

\section{$(\varphi$ \\ K I T L V}

The realization of this publication was made possible by the support of KITLV (Royal Netherlands Institute of Southeast Asian and Caribbean Studies).

Library of Congress Control Number: 2013943621

ISSN 1572-1892

ISBN 978-90-67-18388-8 (hardback)

ISBN 978-90-04-25865-5 (e-book)

Copyright 2013 by Lydia Kieven

This work is published by Koninklijke Brill NV. Koninklijke Brill NV incorporates the imprints Brill, Brill Hes \& De Graaf, Brill Nijhoff, Brill Rodopi and Hotei Publishing.

Koninklijke Brill NV reserves the right to protect the publication against unauthorized use and to authorize dissemination by means of offprints, legitimate photocopies, microform editions, reprints, translations, and secondary information sources, such as abstracting and indexing services including databases. Requests for commercial re-use, use of parts of the publication, and/or translations must be addressed to Koninklijke Brill NV.

This book is printed on acid-free paper. 


\section{Contents}

ACKNOWLEDGEMENTS IX IX

TECHNICAL NOTES $\quad$ XI

LIST OF FIGURES, TABLES, AND PLATES XIII

I INTRODUCTION 1

introducing the subject 2

previous research 5

methodology 11

outline 15

II NARRATIVE RELIEFS AND PANJI STORIES 19

narrative reliefs and literary traditions $\quad 19$

panji stories $\quad 25$

the literary genre $\quad 25$

previous research $\quad 31$

symbolism of the panji stories 38

narratives, panji stories, and performing arts $\quad 47$

III ICONOGRAPHY OF THE LATE EAST JAVANESE TEMPLE RELIEFS $\quad 5^{1}$

iconographical conventions in the late east javanese temple reliefs 51

types of characters $\quad 52$

types of postures $\quad 56$

types of place 58

the cap-figures 60

the term 'cap' 60

iconography and classification $\quad 62$

the kadeyan: gambyok relief and grogol statues $\quad 66$

the gambyok relief 68

$\begin{array}{ll}\text { the grogol statues } & 71\end{array}$

further kertolo statues $\quad 73$ 
IV TEMPLES IN CONTEXT OF RELIGION AND POLITICS

architecture of the majapahit period $\quad 75$

the religious belief systems: saiwism and buddhism 78

tantrism 82

religious practices in majapahit temples 93

the politics of majapahit 96

temples in the 'unity of the realm' 103

the decline of majapahit - mountain sanctuaries 107

water and mountain in ancient javanese mythology and art 113

V TABLE OF DEPICTIONS OF CAP-FIGURES IN MAJAPAHIT ART IN CHRONOLOGICAL ORDER $\quad 123$

$\begin{array}{ll}\text { selection of case studies } & 137\end{array}$

VI CANDI JAGO: THE CAP, A NEW FASHION OF HEADGEAR 143

layout and architecture 144

history and function 144

reliefs with cap-figures $\quad 145$

$\begin{array}{ll}\text { tantri stories } & 145\end{array}$

$\begin{array}{ll}\text { angling dharma story } & 147\end{array}$

kunjarakarna story 150

sudhanakumara-awadana story 152

conclusion $\quad 154$

VII CANDI PANATARAN: PANJI, INTRODUCING THE PILGRIM INTO THE TANTRIC DOCTRINE $\quad 161$

layout and architecture $\quad 161$

history and function $\quad 166$

iconography and interpretation of the reliefs with cap-figures $\quad 171$

$\begin{array}{ll}\text { the outer bathing place } & 171\end{array}$

$\begin{array}{ll}\text { the pendopo terrace }(C) & 173\end{array}$

analysis of the symbolic meaning of the reliefs on the pendopo terrace 201

the naga temple $(E) \quad 210$

the small pendopo terrace $(F) \quad 214$

the dwarapala in front of the main temple 218

the main temple $(G) /(H) \quad 221$

the inner bathing place (I) 229

conclusion $\quad 232$ 
VIII CANDI SUROWONO: SIDAPAKSA, A NOBLEMAN WITH A CAP

layout and architecture

history and function

iconography and interpretation of the narrative reliefs

the sri tanjung reliefs

the arjunawiwaha reliefs and the bubukshah reliefs

cross-references between the three narrative relief series

conclusion

addendum: further cap-figures

IX CANDI MIRIGAMBAR: PANJI, THE IDEAL LOVER AND WARRIOR

X SANCTUARIES ON MOUNT PENANGGUNGAN: CANDI

KENDALISODO, CANDI YUDHA, AND THE PANJI STATUE

FROM CANDI SELOKELIR - THE CLIMAX

geographical situation and layout of the sanctuaries

history and function of the sites

candi kendalisodo

candi yudha

the panji statue from candi selokelir

conclusion

XI CONCLUSION: PANJI AND THE CAP-FIGURE AS INTERMEDIARY

CHARACTERS ON THE PATH TO TANTRIC RITUALS

APPENDIX: PREVIOUS RESEARCH ON THE SINGLE CASE STUDIES 
Lydia Kieven - 9789004258655

Downloaded from Brill.come4/26/2023 02:08:07PM via free access 


\section{Acknowledgements}

This book is the product of my long-term interaction with temples in Java and many people from various countries who inspired and supported me. It is based on my $\mathrm{PhD}$ dissertation, completed in 2008 at the University of Sydney, which I reworked and expanded by rearranging and illuminating various points and by adding more recent findings.

I am indebted to the University of Wollongong for granting me a one-year scholarship and to the Faculty of Arts at the University of Sydney for granting me a follow-up scholarship for another year and a half. These grants enabled me to finalize a study I had started earlier, but which I had never worked on continuously due to my critical financial situation.

I am most grateful to my supervisor, Prof. Adrian Vickers, for making it possible for me to cross the water from my home country Germany to Australia. Our discussions were enormously helpful in giving me inspiration and motivating me, even more so because of his own enthusiasm for the Panji subject. I am deeply indebted to my associate supervisor, Prof. emer. Peter Worsley, for letting me share his broad and deep knowledge on the material and for his commitment to giving me illuminating guidance in polishing the 'cap' ever brighter. I thank both supervisors for their support and encouragement.

I am grateful to Prof. Dr. Peter Pink for his guidance through the first steps in my thesis during my affiliation with the University of Cologne in Germany, and to my associate supervisor at the University of Wollongong, Prof. Diana Wood Conroy.

I wish to thank the libraries and the librarians at Fisher Library at the University of Sydney, the library at KITLV in Leiden, and the Kern Institute in Leiden for providing me with immensely important books, articles and photographical material from the Dutch Archaeological Service. I am grateful for the assistance I received at the Balai Pelestarian Peninggalan Purbakala (BP3) and the museum in Trowulan, the Museum Nasional in Jakarta, and the library of the faculty of arts at ITB Bandung (Institut Teknologi Bandung). 
I wish to thank my colleagues, who have accompanied and helped me throughout the years: Prof. Marijke Klokke, Pauline Lunsingh-Scheurleer, and in particular my examiners, Prof. Helen Creese, Dr. Jan Fontein, and Prof. John Miksic, whose comments on the thesis have contributed in a fundamental way to the shaping of this book. I feel indebted to Tom van den Berge of KITLV Press for initiating this book to be published, and to the whole staff of KITLV - Harry Poeze, Rosemarijn Hoefte, Ellen Sitinjak, Hanneke Teunissen, and the anonymous 'Indonesia Specialist' for their support and for the meticulous work of editing the manuscript.

I feel deeply indepted to $\mathrm{Ki}$ Padmapuspita almarhum from Universitas Gajah Mada who gave me the initial idea of searching for Panji. I would like to thank my Indonesian colleagues Bapak M. Dwi Cahyono from Universitas Negeri Malang, who was an invaluable source for finding many of the reliefs depicting cap-figures, even in very remote sites, Prof. Dr. Agus Aris Munandar from Universitas Indonesia in Jakarta for discussions about Panji, and Bapak Aji Damais for helping to find the Panji sculpture in Bandung. My special thanks to Bapak Suryo Prawiroatmojo from Trawas for his inspiring discussions about Panji. Also to the staff of the PPLH Seloliman for housing me during my fieldtrips. I am deeply grateful to Mas Agus Bimo Prayitno for his patience, motivation, inspiration, and support as a companion in our visits to temples and sites in East Java and for all the discussions which opened my eyes and heart to a deeper understanding of the temples. I am also grateful to all the juru kunci (temple guards) who opened doors for me in both the practical and figurative sense, particularly Mas Bondan in Candi Panataran, and Bapak Paidan who guided me several times on Mount Penanggungan. My thanks also go to all the people in Java who helped me, by bringing me by car or by foot to remote sites, by providing me with hot coffee, by allowing me to take a bath in holy water places, and in many other ways.

I wish to thank my friends and relatives in Germany, my friends in the Netherlands, in Indonesia and in Australia for their support and for motivating me to go on and finish the thesis and the book. My special thanks to my parents, who were very patient with me while I was far away doing this 'crazy' research, and to my aunt.

Last but not least I want to express my deepest thanks to the creators of the beautiful temple reliefs which have attracted and inspired me over and over again, and to Panji who taught me never to give up. 


\section{Technical notes}

Words in languages other than English - that is, Indonesian, Javanese, Old Javanese, and Dutch - are written in italics. The Indonesian and (Old) Javanese terms are explained separately in the glossary at the end of this book.

Sanskrit words and names have been transliterated according to the Javanese spelling system which renders ' $\mathrm{v}$ ' to ' $\mathrm{w}$ ', as in 'Wishnu'. No diacritics are used. For the letters 's' and 'r', I keep to the following conventions:

s - Ardhanariswara, Saka, Sakti, Siwa, sraddha,

- pradakshina, rshi, Wishnu,

r - amerta, Kertanagara, Krishna, Nagarakertagama, rshi.

The Javanese language has two different spellings for the vowel 'a': 'å' / 'o'. I follow the usual and current Indonesian spelling, writing, for example, Janggala (not: Jenggolo or Jenggala), Kertolo (not: Kertala), Kendalisodo (not: Kendalisada), Surowono (not: Surawana), 'Singasari' for the historical kingdom, and 'Singosari' for the temple. Other specific spellings are: kadeyan (not: kadehan) and panakawan (not: punakawan).

To indicate the plural of Javanese and Indonesian words, I do not add the English plural-s; for example, candi means 'temple' or 'temples', depending on the context.

Some particular abbreviations are used in the text:

$\mathrm{AD}$ - years in modern era

AW - Arjunawiwaha

Awj. - Arjunawïjaya

Nag. - Nagarakertagama

OD - Oudheidkundige Dienst (Dutch Archaeological Service)

Par. - Pararaton

Sut. - Sutasoma 
Instead of the name Desawarnana, I use the name Nagarakertagama due to older convention.

Photographs and maps of temples are provided by myself. Otherwise the sources are indicated. I make use of photographs by Ann Kinney (2003) and by the Kern Institute in Leiden. In the descriptions of reliefs and photographs, 'right' and 'left' refer to the viewer's perspective. 
List of figures, tables, and plates

\section{Frontispiece}

Detail of fig. 7.28 (left part of panel 80 of the Pendopo Terrace at Candi Panataran)

\section{Chapter I Introduction}

Fig. 1.1

Panji sculpture from Candi Selokelir (fig. 10.13a);

Candi Panataran, Pendopo Terrace, panel 4 (fig. 7.6);

Candi Panataran, Pendopo Terrace, detail of panel

54 (fig. 7.21); Candi Jago, Kunjarakarna, initiation of Purnawijaya; Candi Jago, Tantri story (detail of fig. 6.5)

\section{Chapter III Iconography of the late East Javanese temple reliefs}

Fig. 3.1 Panji with a crescent-moon shaped cap on the Pendopo Terrace at Candi Panataran

Fig. 3.2 Servants with a half-moon shaped cap on the Main Temple at Candi Panataran

Fig. 3.3 Commoner with a beret-like cap on Candi Jago

Fig. 3.4 Panji sculpture from Candi Selokelir

Fig. 3.5 Relief from Gambyok

Fig. 3.6 The Grogol statues

\section{Chapter IV}

Fig. 4.1

\section{Chapter VI}

Plate 6.1

Fig. 6.2

Fig. 6.3

Fig. 6.4

\section{Temples in context of religion and politics}

The system of the cakra

\section{Gandi Jago}

Groundplan of Candi Jago

Candi Jago, west front

Candi Jago, north side of first terrace at west projection, 'Crocodile and bull'

Candi Jago, north side of first terrace at west projection, 'Monkey and ungrateful man' 
Fig. 6.5 Candi Jago, west side of first terrace at west projection, 'Palmwine tappers judge between monkeys'

Fig. 6.6

Fig. 6.7

Fig. 6.8

Fig. 6.9

Fig. 6.10

Fig. 6.11

\section{Chapter VII}

Plate 7.1

Fig. 7.2

Table 7.3

Fig. 7.4

Plate 7.5

Fig. 7.6

Fig. 7.7

Fig. 7.8

Fig. 7.9

Fig. 7.10

Fig. 7.11

Fig. 7.12

Fig. 7.13

Fig. 7.14

Fig. 7.15

Fig. 7.16

Fig. 7.17

Fig. 7.18

Fig. 7.19
Candi Jago, south side of first terrace, Angling Dharma Candi Jago, first terrace, left part of east side, Angling Dharma

Candi Jago, first terrace, right part of east side, Angling Dharma

Candi Jago, north side of first terrace, Kunjarakarna, Kunjarakarna's initiation

Candi Jago, west front of the belt, Kunjarakarna, parade of the sinners

Candi Jago, north side of the belt, SudhanakumaraAwadana

\section{Candi Panataran}

Groundplan of Candi Panataran

(based on Bernet Kempers 1959:91, fig. 10, with numeration by Kieven)

Candi Panataran, entrance to the temple compound Inscriptions found in the precinct of Candi Panataran

Outer Bathing Place, relief fragment

Groundplan of the Pendopo Terrace

Pendopo Terrace, east side, panel 4

Pendopo Terrace, east side, panels 9-10

Pendopo Terrace, east side, panels 13-14

Pendopo Terrace, east side, panels 15-16

Pendopo Terrace, east side, panel 19

Pendopo Terrace, east side, panel 24

Pendopo Terrace, east side, panel 26

Pendopo Terrace, east side, panels 33-34

Pendopo Terrace, east side, panels 36-38

Pendopo Terrace, north side, panel 43

Pendopo Terrace, north side, panel 44

Pendopo Terrace, north side, panel 46

Pendopo Terrace, west side, panel 49

Pendopo Terrace, west side, panel 51 
Fig. 7.20

Fig. 7.21

Fig. 7.22

Fig. 7.23

Fig. 7.24

Fig. 7.25

Fig. 7.26

Fig. 7.27

Fig. 7.28

Table 7.29

Fig. 7.30

Fig. 7.31

Fig. 7.32

Fig. 7.33

Fig. 7.34

Fig. 7.35

Fig. 7.36

Fig. 7.37

Fig. 7.38

Fig. 7.39

Fig. 7.40

Fig. 7.41

Fig. 7.42a/b

Fig. 7.43

Fig. 7.44

Fig. 7.45

Fig. 7.46
Pendopo Terrace, west side, panel 53

Pendopo Terrace, west side, panels 54-55

Pendopo Terrace, west side, panel 56

Pendopo Terrace, west side, panel 59

Pendopo Terrace, west side, panel 61

Pendopo Terrace, west side, panel 65

Pendopo Terrace, west side, panels 70-71

Pendopo Terrace, south side, panel 75

Pendopo Terrace, south side, panel 80

The elements of the narrative plots on the Pendopo

Terrace and their placement

Pendopo Terrace, west side, panel 56

Naga Temple in the second courtyard, view of south side

Naga Temple, panel on southeastern corner

Small Pendopo Terrace in the third courtyard, to the southwest of the Main Temple

Small Pendopo Terrace, panel on west side

Small Pendopo Terrace, panel on south side

Small Pendopo Terrace, panel on east side

Small Pendopo Terrace, panel on north side

Dwarapala on the right side of the left staircase of the Main Temple

Back of the dwarapala on the left side of the left staircase of the Main Temple

Main Temple in the third courtyard, view from northwest

Main Temple, first terrace, east side, Ramayana, plate 189

Main Temple, second terrace, west side, Krishnayana, panel 5 and detail

Main Temple, second terrace, west side, Krishnayana, part of panel 21

Inner Bathing Place, corner on the south side

Inner Bathing Place, left side of the northern corner, female figure

Inner Bathing Place, right side of the northern corner, male figure 


\section{Chapter VIII Candi Surowono}

Plate 8.1

Fig. 8.2

Fig. 8.3

Fig. 8.4

Fig. 8.5

Fig. 8.6

Fig. 8.7

Fig. 8.8

Fig. 8.9

Fig. 8.10

Fig. 8.11

Fig. 8.12

Fig. 8.13

Fig. 8.14

Chapter IX

Plate 9.1

Fig. 9.2

Fig. $9.3 \mathrm{a} / \mathrm{b}$

Fig. 9.4

Fig. 9.5

Fig. 9.6

Fig. 9.7

Fig. 9.8

Fig. 9.9

Fig. 9.10

Fig. 9.11
Groundplan of Candi Surowono

Candi Surowono, north side, Sri Tanjung, panel 7

Candi Surowono, south side, from right to left: panels 2, A12, A13, A15, A16

Candi Surowono, south side, Sri Tanjung, panel 1

Candi Surowono, south side, right corner, Sri Tanjung, panel 3

Candi Surowono, east side, left corner, Sri Tanjung, panel 4

Candi Surowono, north side, Sri Tanjung, panel 5

Candi Surowono, north side, Sri Tanjung, panel 6

Candi Surowono, north side, Sri Tanjung, left: panel 7; right: panel 8

Candi Surowono, north side, Sri Tanjung, left: A4; right: panel 9

Candi Surowono, seen from the west

Candi Surowono, south side, porch, A15 with

Niwatakawaca and cap-figure

Candi Surowono, small panel on lower range of wall: north side, under panel 5

Candi Surowono, small panel on lower range of wall: east side, under A2

\section{Candi Mirigambar}

Groundplan of Candi Mirigambar

Candi Mirigambar, seen from the west

Candi Mirigambar, figures to the left and right of the staircase

Candi Mirigambar, west side, left of staircase, panel 1

Candi Mirigambar, north side, panel 2

Candi Mirigambar, north side, panel 3

Candi Mirigambar, north side, panel 4

Candi Mirigambar, east side, panel 5

Candi Mirigambar, east side, panel 6

Candi Mirigambar, south side, panel 8

Candi Mirigambar, south side, panel 9 
Fig. 9.12

Fig. 9.13

Ghapter X

Fig. 10.1

Plate 10.2

Fig. 10.3

Fig. 10.4

Fig. 10.5

Fig. 10.6a

Fig. 10.6b

Fig. 10.7a

Fig. 10.7b

Fig. 10.8

Fig. 10.9

Fig. 10.10

Fig. 10.11

Fig. 10.12

Fig. 10.13a

Fig. 10.13b-d

\section{Ghapter XI}

Fig. 11.1

Fig. 11.2
Candi Mirigambar, south side, panel 10

Candi Mirigambar, south side, panel 11

\section{Sanctuaries on Mount Penanggungan}

Mount Penanggungan, seen from Trawas, from the south

Topographic map of Mount Penanggungan

Candi Kendalisodo, view from northwest

Candi Kendalisodo, pemujaan, first terrace, left of staircase, panel 1

Candi Kendalisodo, pemujaan, first terrace, right of staircase, panel 2

Candi Kendalisodo, pemujaan, second terrace, right of staircase, panel 3 (photo 1996)

Candi Kendalisodo, pemujaan, detail of panel 3 (photo 2010)

Candi Kendalisodo, pemujaan, second terrace, left of staircase, panel 4 (photo 1996)

Candi Kendalisodo, pemujaan, detail of panel 4 (photo 2010)

Candi Kendalisodo, pertapaan, Bhima relief

Candi Yudha

Candi Yudha, first terrace, right side of the staircase

Candi Yudha, first terrace, left side of the staircase

Candi Yudha, panel on the third terrace, depicting

Sugriwa and Hanuman

Panji sculpture from Candi Selokelir

Details of the Panji sculpture from Candi Selokelir

\section{Conclusion}

Cap-figure in panel 3 at the Pendopo Terrace of Candi Panataran

Panji sculpture from Candi Selokelir, view from the top 